\title{
MORPHOLOGY, MINERALOGY AND MICROMORPHOLOGY OF SOILS ASSOCIATED TO SUMMIT DEPRESSIONS OF THE NORTHEASTERN BRAZILIAN COASTAL PLAINS
}

\author{
Morfologia, mineralogia e micromorfologia de solos de depressões de topo de \\ Tabuleiros Costeiros do Nordeste Brasileiro
}

\author{
Elen Alvarenga Silva1, João Bosco Vasconcellos Gomes², José Coelho de Araújo Filho³, \\ Pablo Vidal-Torrado ${ }^{4}$, Miguel Cooper ${ }^{4}$, Nilton Curi ${ }^{5}$
}

\begin{abstract}
The scarcity of comprehensive characterizations of soils associated to gentle summit depressions of the Northeastern Brazilian Coastal Plains justifies this work, which had as objective to provide basic information for the more diverse agricultural and non-agricultural uses. For that, representative soils (Spodosols or similar soils) from these environments were selected in Alagoas, Sergipe and Bahia states. This approach included characterization of morphological, mineralogical and micromorphological properties of the soil profiles, employing standard procedures. The morphological characterization corroborated the effect of the podzolization process during the formation of these soils. The mineralogy of the clay fraction of these soils was basically composed of kaolinite and quartz, which, associated to the very sandy texture, helped in the understanding of the obtained data. The soil micromorphological study, besides confirming the field morphology, mainly in regard to the strong cementation, aggregated value to the work in terms of the secure identification of the clay illuviation process (non-identified in the field), in association with the dominant podzolization process.
\end{abstract}

Index terms: Sand-quartzous soils, cementation, hydromorphism, podzolization, Barreiras Formation.

\section{RESUMO}

A carência de caracterizações abrangentes de solos associados às depressões suaves de topo dos Tabuleiros Costeiros do nordeste brasileiro justifica este trabalho, o qual objetivou fornecer informações básicas para as mais diversas finalidades agrícolas e não-agrícolas. Para tal, foram selecionados solos representativos (Espodossolos ou solos afins) desses ambientes nos estados de Alagoas, Sergipe e Bahia. A abordagem utilizada englobou a caracterização de atributos morfológicos, mineralógicos e micromorfológicos de perfis dos solos, empregando-se metodologia padronizada. A caracterização morfológica corroborou o efeito do processo de podzolização na formação desses solos. A mineralogia da fração argila desses solos foi composta basicamente por caulinita e quartzo, o que, ao lado da textura muito arenosa, ajudou na compreensão dos dados obtidos. O estudo micromorfológico do solo, além de confirmar a morfologia de campo, particularmente no tocante à forte cimentação, agregou valor ao trabalho em termos da identificação inequívoca do processo de argiluviação (não identificada no campo) em associação ao processo dominante de podzolização.

Termos para indexação: Solos arenoquartzosos, cimentação, hidromorfismo, podzolização, Formação Barreiras.

(Received in july 3, 2012 and approved in august 10, 2012)

\section{INTRODUCTION}

Coastal Plains are landscapes of sedimentary origin in the Brazilian Coast from the state of Rio de Janeiro to Amapá, being limited on the East by the coastal lowlands and on the West by the crystalline basement rock, occupying around 20 million hectares. That area is dominated by cohesive Yellow Argisols and Latosols derived from sandy-clayey sediments of the Barreiras Formation (SANTANA et al., 2006; MELO FILHO;
SOUZA; SOUZA, 2007; CORRÊA et al., 2008a; CINTRA et al., 2009).

In those Plains, gentle depressions exist where the summit is more extensive, in which differentiated soils, under various aspects, occur. In those depressions, Spodosols or intermediate soils to them (soils with illuvial accumulation of carbon and aluminum with or without iron, in which the color and, or, cementing characteristics do not meet the requirements for characterizing a spodic

\footnotetext{
'Universidade Federal de Lavras/UFLA - Departamento de Ciência do Solo/DCS - Cx. P. 3037 - 37200-000 - Lavras - MG - Brasil elenalvarenga@yahoo.com.br

${ }^{2}$ Empresa Brasileira de Pesquisa Agropecuária/Embrapa - Embrapa Florestas - Colombo - PR - Brasil

${ }^{3}$ Empresa Brasileira de Pesquisa Agropecuária/Embrapa - Embrapa Solos - Recife - PE - Brasil

"Universidade de São Paulo/USP - Escola Superior de Agricultura "Luiz de Queiroz"/ESALQ - Departamento de Solos e Nutrição de Plantas Piracicaba - SP - Brasil

${ }^{5}$ Universidade Federal de Lavras/UFLA - Departamento de Ciência do Solo/DCS - Lavras - MG - Brasil
} 
B horizon) are very frequent, the majority of which present cemented horizons and features associated to the excess of water (MOREAU et al., 2006a; CORRÊA et al., 2008b). The presence of these depressions causes a lateral flow of water towards them, providing reducing conditions with the installation of perched water tables, causing the soil evolution sequence to be in the fragipan-duripan direction (FILIZOLA et al., 2001; MELLO; CURI, 2012).

Spodosols are mineral soils, hydromorphic or not, with spodic B horizon within the first $400 \mathrm{~cm}$ of depth, underlying the albic E horizon or another elluvial (of loss) horizon and they are typically sandy and acid (EMPRESA BRASILEIRA DE PESQUISA AGROPECUÁRIA EMBRAPA, 2006). The spodic horizon is usually formed by the translocation of active amorphous materials, composed of organic matter and $\mathrm{Al}$ with or without $\mathrm{Fe}$. They are soils of fast surface drainage, which may be impeded at depth when the spodic horizon is cemented and continuous, raising the water table during the rainy period, imposing hydromorphic conditions to the soil (RESENDE et al., 2007; SAUER et al., 2007).

There are two theories to explain the $\mathrm{Fe}$ and $\mathrm{Al}$ remotion from elluvial horizons and its accumulation in the B horizon (KÄMPF; CURI, 2012). By according to the protoimogolite theory, which is more applicable to conditions (low soil organic matter - SOM accumulation), hydrosols of hydroxy Al-Si and $\mathrm{Fe}$ in solution, originated from weathering in $\mathrm{A}$ and $\mathrm{E}$ horizons, are transported and precipitated in the $\mathrm{B}$ horizon in the form of materials like imogolite and $\mathrm{Fe}$ oxides; the transport and accumulation of organic compounds in the B horizon would occur in a further stage. This would explain the occurrence of spodic horizons low in humus, which are typical of Northeastern Brazilian conditions and very distinct from the complexation theory, which is more applicable to temperate conditions.

The proximity of Coastal Plains to the coast has imposed high pressure for the occupation of those lands. The native vegetation was almost totally removed and substituted by agricultural activities such as the sugarcane, pastures, reforestation with eucalyptus and, to a lesser degree, horticulture. From a soil use point of view, those depressions are avoided during the planting plan (CORRÊA et al., 2008b), but many times are used without specific management, since the spatial variability of soils in Coastal Plain summit areas has been neglected by managers (GOMES et al., 2008). It results in productivity decreases and a retreat from environmental sustainability.

Researches that thoroughly characterize the soils of those depressions are still scarce. Thus, the objective of this work was to characterize the morphological, mineralogical and micromorphological attributes of representative profiles of soils derived from the Barreiras Formation associated to the depressions of the gentle summit of the Northeastern Brazilian Coastal Plains, seeking to supply basic information for the most diverse agricultural and non-agricultural uses.

\section{MATERIAL AND METHODS}

Four soil profiles from gentle depression areas associated to Coastal Plain summits in the states of Alagoas (AL), Sergipe (SE) and Bahia (BA) were described and sampled (Table 1). The locations of profiles are shown in figure 1. At each site a trench was opened to conduct the morphological description according to Santos et al. (2005) and samples of the horizons of each profile were collected for laboratory analyses.

The parent material of the studied soils predominantly includes sand-quartzous sediments from Barreiras Formation and the native vegetation is represented mainly by the sub-perennial tropical forest (field evidence).

The area of Nova Viçosa, BA, presents a tropical climate with all of the months being rainy (the driest month presents more than $60 \mathrm{~mm}$ of rain). The areas of Coruripe, AL, Neópolis, SE, and Acajutiba, BA, are under a tropical rainy climate with dry summer (SILVA et al., 1993).

Table 1 - Code, county and current use of the areas studied.

\begin{tabular}{cccccc}
\hline Code & County & State & \multicolumn{2}{c}{ Coordinates } & Current use \\
\hline & & & Latitude & Longitude & \\
\hline CF & Coruripe & AL & $10^{\circ} 03^{\prime} 41^{\prime \prime} \mathrm{S}$ & $36^{\circ} 12^{\prime} 26^{\prime \prime} \mathrm{WGr}$ & Altered primary forest \\
$\mathrm{NC}$ & Neópolis & $\mathrm{SE}$ & $10^{\circ} 19^{\prime} 21^{\prime \prime} \mathrm{S}$ & $36^{\circ} 40^{\prime} 38^{\prime \prime} \mathrm{WGr}$ & Coconut plantation \\
$\mathrm{AE}$ & Acajutiba & $\mathrm{BA}$ & $11^{\circ} 41^{\prime} 50^{\prime \prime} \mathrm{S}$ & $38^{\circ} 01^{\prime} 01^{\prime \prime} \mathrm{WGr}$ & Eucalyptus plantation \\
$\mathrm{VE}$ & Nova Viçosa & $\mathrm{BA}$ & $17^{\circ} 50^{\prime} 23^{\prime \prime} \mathrm{S}$ & $39^{\circ} 41^{\prime} 23^{\prime \prime} \mathrm{WGr}$ & Eucalyptus plantation \\
\hline
\end{tabular}

Ciênc. agrotec., Lavras, v. 36, n. 5, p. 507-517, set./out., 2012 


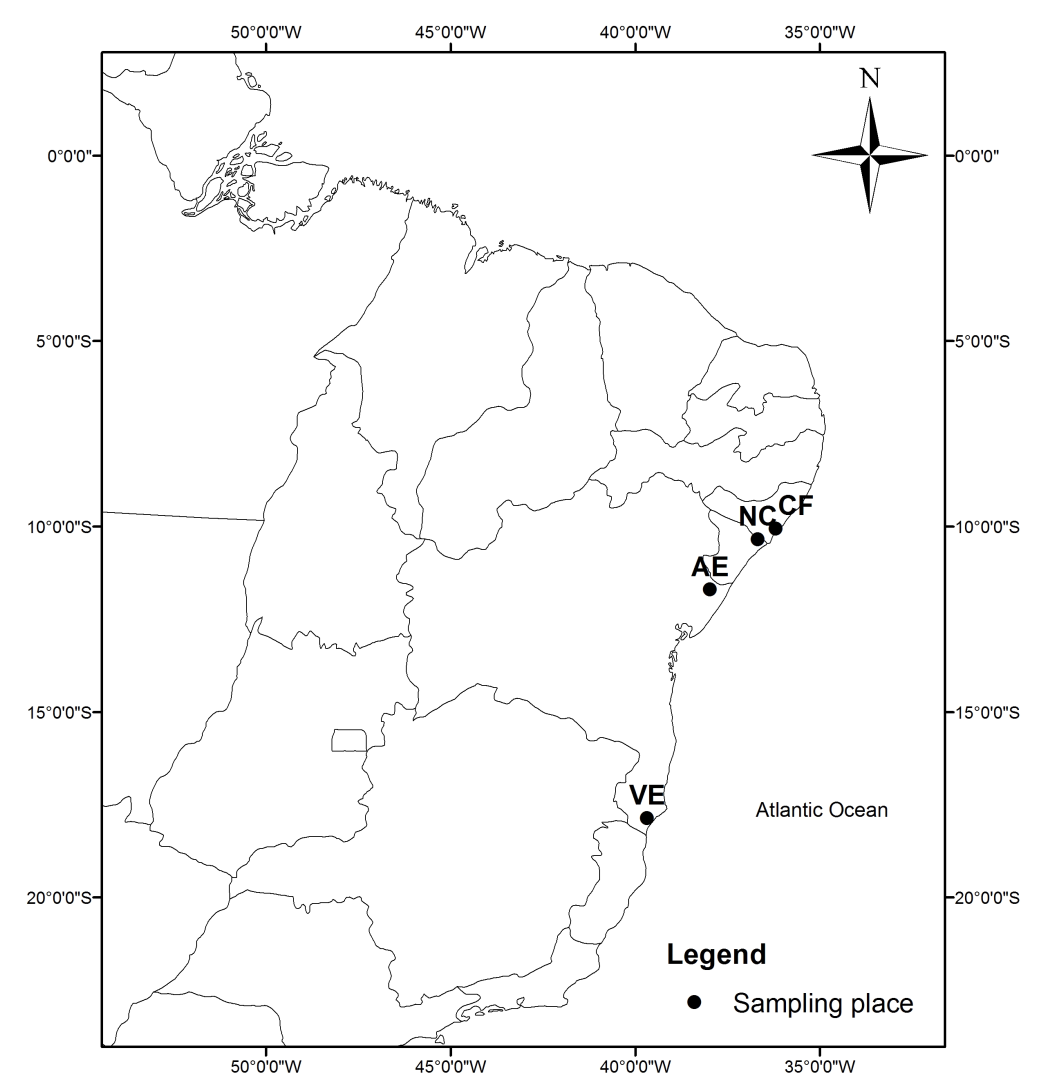

Figure 1 - Location of the studied soils. Profile code: $\mathrm{CF}=$ Coruripe forest; $\mathrm{NC}=$ Neópolis coconut; $\mathrm{AE}=$ Acajutiba eucalyptus; VE = Nova Viçosa eucalyptus.

The mineralogical characterization of the soils was conducted on the clay fraction saturated with $\mathrm{Na}^{+}$, using $\mathrm{X}$-ray diffraction $(35 \mathrm{kV}, 25 \mathrm{~mA}$ and $\mathrm{CoK}$, radiation). In some samples, in which peak position displacement of some minerals was observed, halite was added as internal standard for instrumental correction of the reflection positions of these minerals (RESENDE et al., 2011).

For the micromorphological characterization, thin sections were prepared from undisturbed samples. The samples were impregnated with polyester resin and later sectioned. The thin sections were prepared according to Castro et al. (2003), analyzed in petrographic microscope equipped with polarized light, and described according to Bullock et al. (1985).

\section{RESULTS AND DISCUSSION}

\section{Morphology}

The morphological description of the studied profiles is presented in table 2. All of the profiles have albic $\mathrm{E}$ and spodic $\mathrm{B}$ horizons at different depths and thicknesses. The profiles AE, VE and CF presented cemented horizons (Bsm) just below the spodic horizon. Those cemented horizons presented a moist consistence (most profiles were moisty when described) varying from firm to extremely firm and their presence provokes restriction to the infiltration of water and penetration of roots and, as a consequence, also impedes or hinders leaching of organic compounds outward from the soil system, thus contributing to the podzolization process (OLIVEIRA et al., 2010).

The moist consistence of the spodic horizon of the NC profile was classified as firm, however the description and collection of samples from deeper horizons of this soil was not possible because the water table was suspended and coincided with the spodic horizon.

In the $\mathrm{A}$ and $\mathrm{E}$ horizons of all of the profiles, the structure was framed as simple grains. In the subsurface horizons this varied from subangular blocky to massive, this last being of higher occurrence, mainly in the cemented horizons. It is important to point out that, except for the NC profile, all of the spodic horizons presented a very friable consistence when moist. 


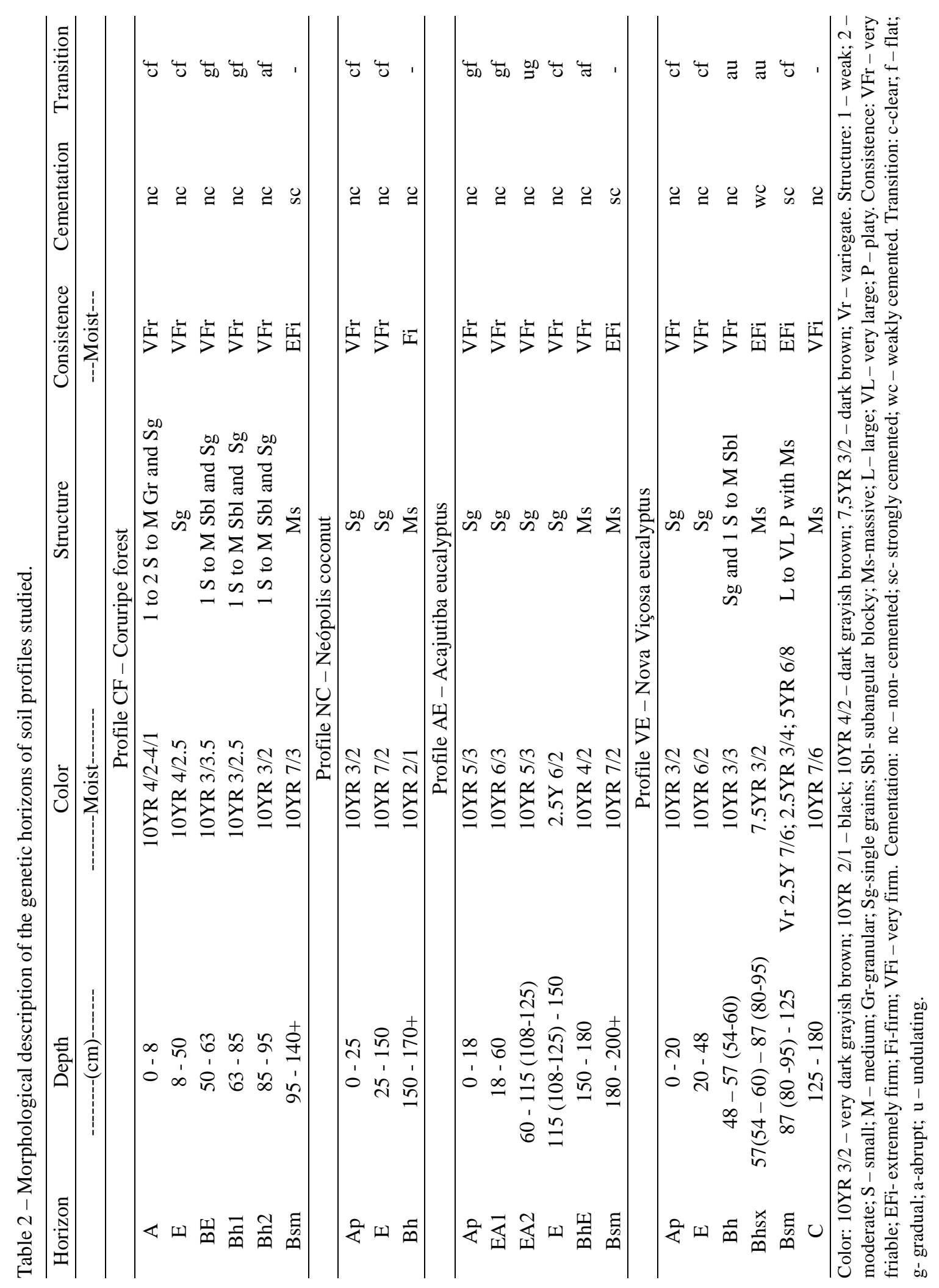

Ciênc. agrotec., Lavras, v. 36, n. 5, p. 507-517, set./out., 2012 
Except for the E horizon of the AE profile and the Bhsx and Bsm horizons of VE profile, the color of the horizons presented a 10YR hue. In general, all of the profiles presented low chroma, indicating hydromorphism in these soils (GOMES et al., 1998; LIMA NETO et al., 2009).

\section{Mineralogy}

The X-ray diffractograms (XRDs) of the clay fraction of the soils are presented in figure 2. In the $\mathrm{AE}$ and $\mathrm{NC}$ profiles, kaolinite, quartz, anatase and rutile were identified (Figures $2 b$ and $2 c$ ). In the spodic horizon of the VE profile (Figure 2d), kaolinite, quartz, anatase and halite (artifact added as internal standard) were identified. In figure 2a, related to the $\mathrm{Bh}$ and Bsm (cemented) horizons

a)

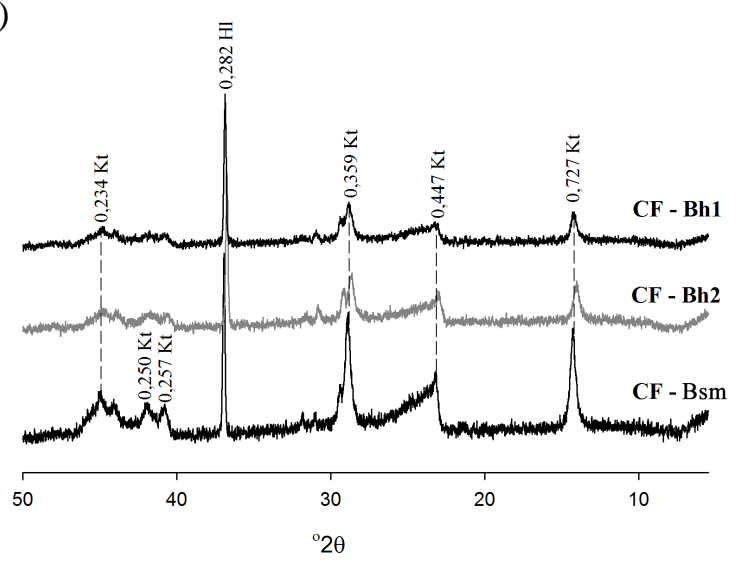

c)

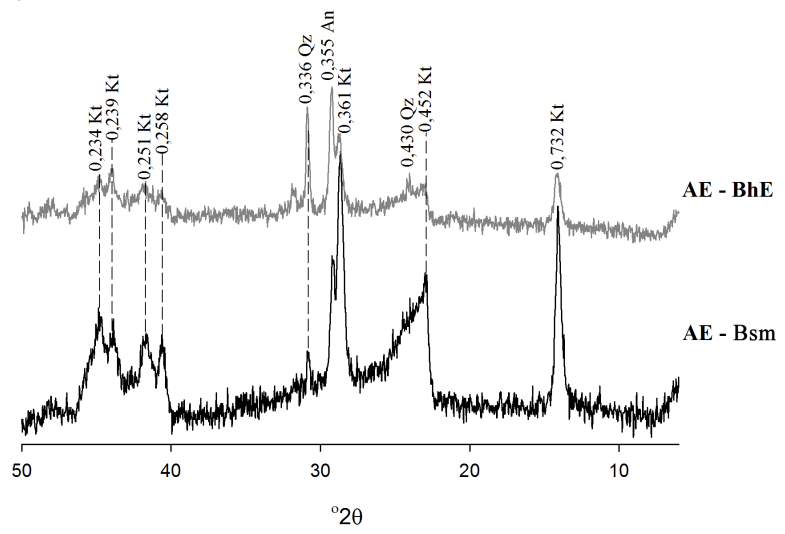

of the CF profile, the interpretation of respective XRDs indicates the kaolinite and the halite artifact occurrence.

Kaolinite as well as quartz occurred in all of the horizons, demonstrating the high mineralogical uniformity of those soils of Northeastern Brazilian Coastal Plains depressions. Those results are in accordance with those found by other authors (LIMA et al., 2004; MOREAU et al., 2006b; CORRÊA et al., 2008a,b; GIAROLA et al., 2009; LIMA NETO et al., 2010). The international literature has registered a great mineralogical diversity in Spodosols of Northern Hemisphere (SKIBA; SKIBA, 2005). The mineralogical uniformity and the relatively simple morphology of the studied soils are characteristic of tropical Spodosols and are very different from the temperate Spodosols.

b)

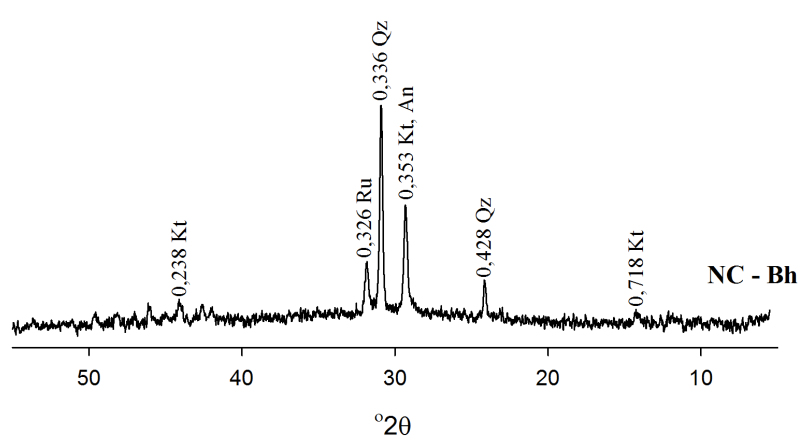

d)

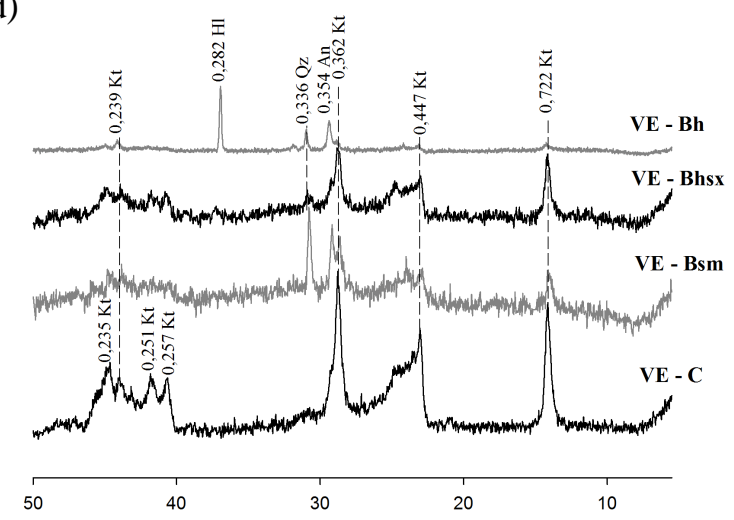

Figure 2 - X-ray diffractograms of clay samples saturated with $\mathrm{Na}^{+}$of subsurface horizons of profiles a) $\mathrm{CF}$; b) NC; c) $\mathrm{AE}$; and d) VE. Kt= kaolinite; $\mathrm{An}=$ anatase; $\mathrm{Qz}=$ quartz; $\mathrm{Ru}=$ rutile; $\mathrm{Hl}=$ halite. Numbers above the peaks correspond to the $\mathrm{d}$ spacing in $\mathrm{nm}$. $\mathrm{CoK}_{\alpha}$ radiation. 
The wide kaolinite dominance in the clay fraction of the subsurface horizons of these soils is due to the fact these soil environments are quite acidic, chemically poor and sandy-quartzous (Tables 3 and 4), where there is slow release of silica to the soil solution, inhibiting the gibbsite formation (RESENDE et al., 2007).

Table 3 - Main micromorphological characteristics of the subsurface horizons of soils.

\begin{tabular}{|c|c|c|c|}
\hline & \multicolumn{3}{|c|}{ Profile $\mathrm{CF}$ - Coruripe forest } \\
\hline & $\mathrm{BE}-\mathrm{Bh} 1$ & $\mathrm{Bh} 1-\mathrm{Bh} 2$ & Bsm \\
\hline Matrix & $\begin{array}{l}\text { Coarse material: } 40 \% \\
\text { Fine material: } 20 \% \\
\text { Porosity: } 40 \%\end{array}$ & $\begin{array}{l}\text { Coarse material: } 40 \% \\
\text { Fine material: } 20 \% \\
\text { Porosity: } 40 \%\end{array}$ & $\begin{array}{l}\text { Coarse material: } 40 \% \\
\text { Fine material: } 45 \% \\
\text { Porosity: } 15 \%\end{array}$ \\
\hline Coarse material & $\begin{array}{l}\text { Rounded grains moderately } \\
\text { spherical and poorly sorted } \\
\text { with grains of various sizes. } \\
\text { Predominant composition of } \\
\text { quartz grains. }\end{array}$ & $\begin{array}{l}\text { Rounded and spherical } \\
\text { grains. Some angular ones. } \\
\text { Grains moderately sorted } \\
\text { with grains of several sizes. } \\
\text { Predominant composition of } \\
\text { quartz grains with absence } \\
\text { of rock fragments. }\end{array}$ & $\begin{array}{l}\text { Composed of angular and } \\
\text { rounded grains, moderately } \\
\text { spherical to spherical, flat, } \\
\text { poorly sorted. Predominant } \\
\text { composition of quartz } \\
\text { grains. Absence of rock } \\
\text { fragments. }\end{array}$ \\
\hline Fine material & $\begin{array}{l}\text { Brownish-red with presence of } \\
\text { organic material. }\end{array}$ & $\begin{array}{l}\text { Organic-mineral conferring } \\
\text { reddish-brown coloration. }\end{array}$ & $\begin{array}{l}\text { Red coloration, argillaceous } \\
\text { material with iron oxides. }\end{array}$ \\
\hline Pores & Packing pores and channels. & $\begin{array}{l}\text { Packing pores, channels, } \\
\text { chambers and cavity pores. } \\
\text { A few pores present } \\
\text { discontinuous filling by } \\
\text { quartz grains and little fine } \\
\text { material. Pores with } \\
\text { wrinkled walls. }\end{array}$ & $\begin{array}{l}\text { Cavity, channels and } \\
\text { chambers. Some pores } \\
\text { (channels) present dense and } \\
\text { continuous filling by fine } \\
\text { material. }\end{array}$ \\
\hline Microstructure & Microgranular. & $\begin{array}{l}\text { Microaggregates among } \\
\text { grains. }\end{array}$ & Massive dense. \\
\hline $\begin{array}{l}\text { Relative } \\
\text { distribution }\end{array}$ & Enaulic, chitonic, gefuric. & Enaulic, chitonic, gefuric. & Porphyric. \\
\hline Birefringent fabric & $\begin{array}{l}\text { Strong and continuous grains } \\
\text { striation. }\end{array}$ & $\begin{array}{l}\text { Weak sprinkled with some } \\
\text { grains with strong striation. }\end{array}$ & $\begin{array}{l}\text { Strong birefringence with } \\
\text { striation in pores and grains. }\end{array}$ \\
\hline $\begin{array}{l}\text { Pedological } \\
\text { features }\end{array}$ & $\begin{array}{l}\text { Grains and pores covered by } \\
\text { fine material (cutans). }\end{array}$ & $\begin{array}{l}\text { Grains covered by fine } \\
\text { material (cutans). Few pores } \\
\text { with loose and } \\
\text { discontinuous filling. } \\
\text { Presence of some clay } \\
\text { nodules and/or organic } \\
\text { material. }\end{array}$ & $\begin{array}{l}\text { Some pores are covered by } \\
\text { cutans of darkened organic } \\
\text { material. Argilluviation } \\
\text { evidence. Complete dense } \\
\text { and loose discontinuous pore } \\
\text { filling. }\end{array}$ \\
\hline
\end{tabular}

Continued... 
Table 3 - Continued...

\begin{tabular}{|c|c|c|}
\hline & $\begin{array}{c}\text { Profile NC }- \text { Neópolis coconut } \\
\text { Bh }\end{array}$ & $\begin{array}{c}\text { Profile AE - Acajutiba eucalyptus } \\
\text { Bsm }\end{array}$ \\
\hline Matrix & $\begin{array}{l}\text { Coarse material: } 60 \% \\
\text { Fine material: } 30 \% \\
\text { Porosity: } 10 \%\end{array}$ & $\begin{array}{l}\text { Coarse material: } 40 \% \\
\text { Fine material: } 60 \% \\
\text { Porosity: } 30 \%\end{array}$ \\
\hline Coarse material & $\begin{array}{l}\text { Composed of angular grains, poorly sorted. } \\
\text { Composed predominantly of quartz grains. } \\
\text { Absence of rock fragments. }\end{array}$ & $\begin{array}{l}\text { Predominantly rounded and some angular; } \\
\text { moderately sorted with relatively similar grain } \\
\text { sphericity; composition dominated by quartz. }\end{array}$ \\
\hline Fine material & $\begin{array}{l}\text { Predominantly organic and darkened, with } \\
\text { some grains with cutan presence. }\end{array}$ & $\begin{array}{l}\text { Strongly striated clay, with iron oxides (red } \\
\text { coloration). }\end{array}$ \\
\hline Pores & Cavity, poly-concave and fissural. & $\begin{array}{l}\text { Cavity, chambers and fissural. Some pores are } \\
\text { filled by quartz grains and Fe ions and organic } \\
\text { matter. The majority of pores present smooth, } \\
\text { irregular walls. }\end{array}$ \\
\hline Microstructure & Aggregrates among grains. & $\begin{array}{l}\text { Microaggregates among grains (in the place } \\
\text { where the grains fill out a larger pore) and } \\
\text { compact. }\end{array}$ \\
\hline $\begin{array}{l}\text { Relative } \\
\text { distribution }\end{array}$ & $\begin{array}{l}\text { Porphyric with microaggregates among } \\
\text { grains. }\end{array}$ & Porphyric. \\
\hline Birefringent fabric & Birefringence was not observed. & $\begin{array}{l}\text { Strongly developed, grooved, mono- grain- and } \\
\text { pore-striated. }\end{array}$ \\
\hline $\begin{array}{l}\text { Pedological } \\
\text { features }\end{array}$ & $\begin{array}{l}\text { Grains covered by cutans of organic } \\
\text { material. Some cavity pores present loose } \\
\text { and discontinuous filling by quartz grains. } \\
\text { Presence of a few nodules of organic } \\
\text { material. }\end{array}$ & $\begin{array}{l}\text { Illuviation cutans, grain and pore cutans, pores } \\
\text { with dense and incomplete filling (with iron } \\
\text { filling), loose continuous filling by quartz } \\
\text { grains, dense and complete filling of pores by } \\
\text { Fe ions and organic matter. }\end{array}$ \\
\hline
\end{tabular}

Profile NC-Neópolis coconut

Horizon-Bhsx

\begin{tabular}{ll}
\hline Matrix & $\begin{array}{l}\text { Coarse material: } 50 \% \\
\text { Fine material: } 30 \%\end{array}$ \\
& $\begin{array}{l}\text { Porosity: } 20 \% \\
\text { Rounded and some angular, poorly sorted with grains of variable sphericity, composition } \\
\text { predominantly dominated by quartz. }\end{array}$ \\
Fine material & $\begin{array}{l}\text { Strongly striated clay, with iron oxides (red coloration). } \\
\text { Pores }\end{array}$ \\
$\begin{array}{l}\text { Microstructure } \\
\text { Cavity, stacking, microfissures. Small poly-concave cavities. } \\
\text { distribution }\end{array}$ & Grumous dense granular/microgranular. \\
Birefringent fabric & Porphyric-enaulic-chitonic. \\
Pedological & Strongly developed, grooved, grain-and pore striated. \\
features & $\begin{array}{l}\text { Grains and pores covered by fine material indicating illuviation cutans. Some pores presented } \\
\text { loose and discontinuous filling for fine material as well as for coarse material. }\end{array}$
\end{tabular}


Another common mineral in the XRDs is quartz, the major diluent of the Brazilian soil environments. As the mineralogy of spodic soils in temperate regions is much more complex than in tropical regions, the diluent effect of quartz (inert material - very low specific surface area) is more pronounced in the last condition. In the context of this study, the effect of the physical, chemical and biological attributes on the behavior of these soils is substantially diluted by the high sand content and the distinct presence of quartz in their clay fractions. In all of the profiles and horizons the predominant particle size fraction was sand, favoring the leaching of organic-metallic complexes and contributing to the podzolization process.

Under tropical conditions, the presence of materials of sandy-quartzous origin and subsurface impediments such as a perched water table and, or, cemented horizon, facilitates the podzolization process, in accordance with Oliveira et al. (2010).

\section{Micromorphology}

In order to evaluate possible differential pedologic features of the soils associated to the depressions on the gentle summit of the Coastal Plains, micromorphological analysis was conducted in spodic and cemented horizons (Table 3 and figures 3 and 4). The coarse fraction practically consists of rounded and some angular quartz, poorly sorted. In a general way, there is predominance of coarse material in the most superficial horizons. On the other hand, in the cemented (Bsm) horizons there is decrease of those coarse materials and porosity, in function of the increase of the fine material.

Table 4 - Classification of soil profiles according to the Brazilian Classification System Embrapa, 2006).

\begin{tabular}{|c|c|c|}
\hline Code & Place & $\begin{array}{l}\text { Soil classification - particle size distribution - depth of spodic horizon or } \\
\text { intermediate horizon }\end{array}$ \\
\hline $\mathrm{CF}$ & Coruripe, AL & duric Orthic Humiluvic Spodosol - sandy /medium - 63 cm \\
\hline $\mathrm{NC}$ & Neópolis, SE & espessarenic Hydromorphic Humiluvic Spodosol- sandy /medium - $150 \mathrm{~cm}$ \\
\hline $\mathrm{AE}$ & Acajutiba, BA & spodic Orthic Quartzarenic Neosol - sandy- $150 \mathrm{~cm}$ \\
\hline VE & Nova Viçosa, BA & fragipanic, duric Orthic Ferrihumiluvic Spodosol - sandy $/$ medium - $48 \mathrm{~cm}$ \\
\hline
\end{tabular}
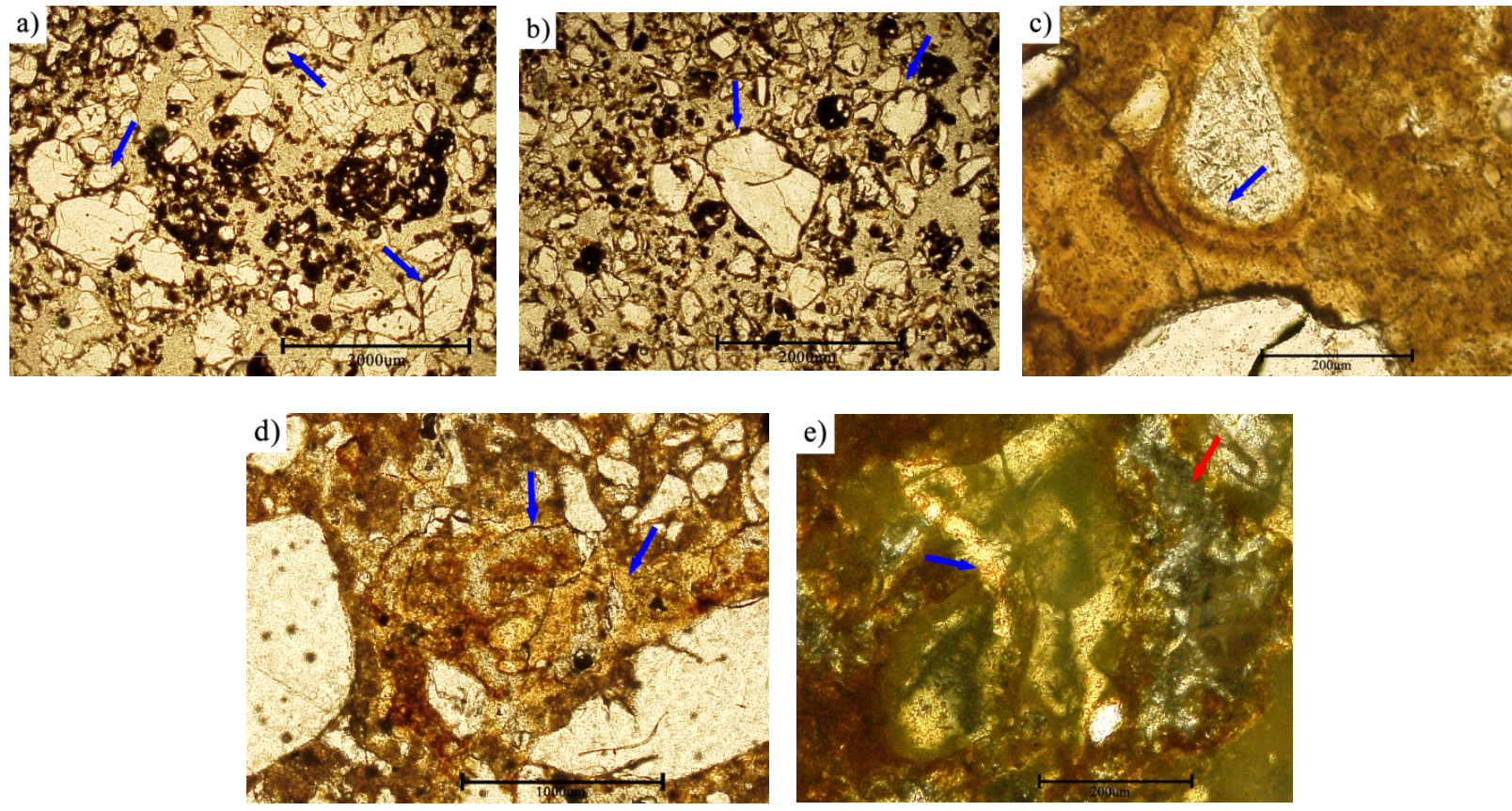

Figure 3 - Micrographs obtained with optical microscope of the soil profiles and horizons: a) CF: BE-Bh1; b) CF: Bh1Bh2; c, d) CF: Bsm; e) CF: Bsm, photographed with polarized light.

Ciênc. agrotec., Lavras, v. 36, n. 5, p. 507-517, set./out., 2012 
The birefringent fabric was differentiated in the cemented (Bsm) horizons, demonstrating a higher organization of clays, which according to Lima Neto et al. (2010), can be the result of the illuviation process in association with the podzolization process in the soil profiles.

Figures $3 \mathrm{a}$ and $3 \mathrm{~b}$ represent the transition of the $\mathrm{BE}-\mathrm{Bh} 1$ and $\mathrm{Bh} 1-\mathrm{Bh} 2$ horizons of the $\mathrm{CF}$ profile, respectively. In the figures it is possible to notice darker materials covering the quartz grains (indicated by arrows). Figures $3 \mathrm{c}, 3 \mathrm{~d}$ and $3 \mathrm{e}$ show the images of the cemented (Bsm) horizon of the same profile. In figure $3 \mathrm{c}$ it is possible to see, in the upper center of the image, a pore with oriented clay (arrow) around it, indicating the occurrence of the argilluviation process. In figure $3 \mathrm{~d}$ a clear segregation of Fe is indicated in the center of the figure (arrow), a feature also indicated under polarized light in figure $3 \mathrm{e}$ (blue arrow). In the latter case, the porosity (red arrow, pore with no connection to other pores) indicates a very closed system in keeping with strong cementation observed in the field morphology.

In figures $4 \mathrm{a}, 4 \mathrm{~b}$ and $4 \mathrm{c}$ are presented the images of the Bh horizon of the NC profile. In Figure $4 \mathrm{a}$ it is possible to see a horizontal band of soil organic matter
(SOM) (arrow) due to the oscillation of the water table. Figure $4 \mathrm{~b}$ displays all the pores well filled with SOM (arrow) (keeping in mind that it is normal light and not polarized - under this last condition the soil pores are black). In figure $4 \mathrm{c}$ it is possible to verify another band of SOM (arrow), in this case, more oblique, also interpreted as a function of the water table oscillation, supporting the morphology findings.

The plasma of figure $4 \mathrm{~d}$ is quite dense and there is evidence of $\mathrm{Fe}$ segregation, mainly in the center of the slide (arrow). In the NE profile (Figures $4 \mathrm{e}$ and $4 \mathrm{f}$ ) the continuous dark coverings are evidenced (arrows), attributed to the dominant podzolization process in these soils.

In these micromorphological analyses the SOM and clay mineral illuviation processes in these soil profiles were indicated. The presence of illuviation cutans composed of clay mineral, organic material and iron was a constant in the examined slides. The clay skins were not identified in the field morphology, however its micromorphological detection in this work (Figure 3c, 3d, 3e e 4d), in association with the podzolization process, has been commonly registered in the international literature in similar soils (BUURMAN, 1984).
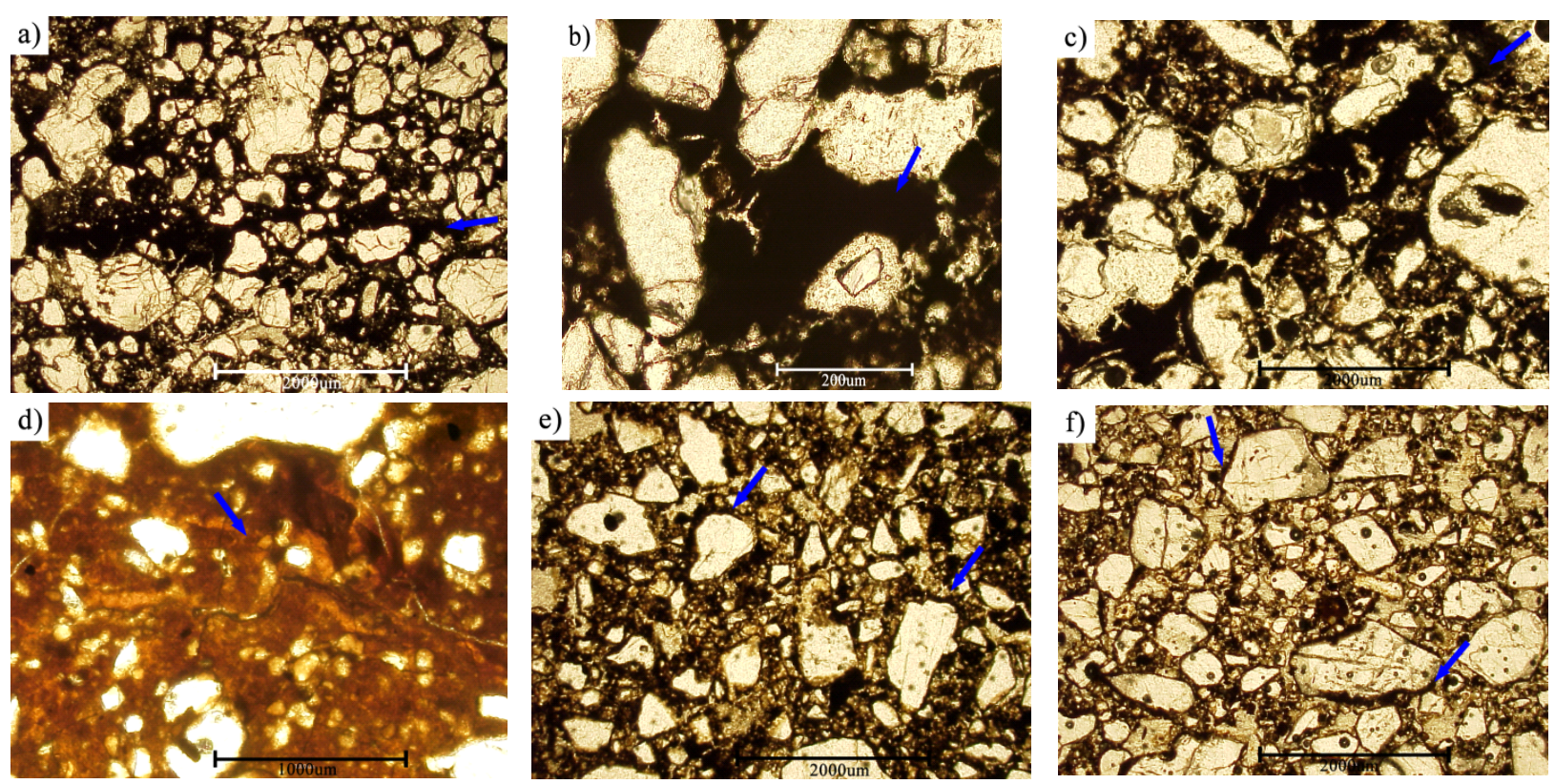

Figure 4-Micrographs obtained with optical microscope of the soil profiles and horizons: a, b, c) NC: Bh; d) AE: Bsm; e, f) NE: Bhsx. 


\section{Soil Classification}

The classification of the profiles of the studied soils is presented in table 4. Except for the AE profile, all the other profiles were classified as Spodosols. Although the AE profile has a spodic character, this was not enough to frame it as a Spodosol, because the BhE horizon, thus identified for not presenting typical morphology of a spodic horizon, having presented high color value (Munsell), presented a low CO content, about $0.52 \mathrm{dag} \mathrm{dm}^{-3}$, and since the Brazilian Soil Classification System (EMBRAPA, 2006) does not define that parameter, we opted to classify it as a Quartzarenic Neosol intermediary to Spodosol.

\section{CONCLUSIONS}

The morphological characterization corroborated the effect of the podzolization process in the formation of these soils.

The mineralogy of the soil clay fraction associated to the depressions of the summit of the Northeastern Brazilian Coastal Plains was basically composed of kaolinite and quartz, which, besides the sandy texture, helped in the understanding of the morphological and micromorphological data.

The micromorphological study of the soil, besides confirming the field morphology, particularly concerning the strong cementation, aggregated value to the work in terms of the unequivocal identification of the argilluviation process (not identified in the field) in association with the dominant podzolization process.

The relatively simple morphology and the homogeneous clay mineralogy of these tropical Northeastern Brazilian Spodosols are much differentiated from the temperate Spodosols.

\section{REFERENCES}

BULLOCK, P. et al. Handbook for soil thin section description. Waine Research Publications, Wolverhampton. 1985. 153p.

BUURMAN, P. Podzols. The Nostrand Van Nostrand Reinhold: Soil Science Series, Washington, 1984. 450p.

CASTRO, S.S. et al. Tópicos em Ciência do Solo. 3. ed. Viçosa: SBCS, 2003. p.07-164.

CINTRA, F.L.D. et al. Efeito de volumes de água de irrigação no regime hídrico de solo coeso dos Tabuleiros e na produção de coqueiro. Revista Brasileira de Ciência do Solo, Viçosa, v.33, n.4, p.1041-1051, 2009.
CORRÊA, M.M. et al. Caracterização física, química, mineralógica e micromorfológica de horizontes coesos e fragipãs de solos vermelhos e amarelos do ambiente Tabuleiros Costeiros. Revista Brasileira de Ciência do Solo, Viçosa, v.32, n.1, p.297-313, 2008 a.

CORRÊA, M.M. et al. Propriedades cristalográficas de caulinitas de solos do ambiente Tabuleiros Costeiros, Amazônia e Recôncavo baiano. Revista Brasileira de Ciência do Solo, Viçosa, v.32, n.5, p.1857-1872, 2008b.

\section{EMPRESA BRASILEIRA DE PESQUISA} AGROPECUÁRIA- EMBRAPA. Sistema brasileiro de classificação de solos. 2. ed. Rio de Janeiro: Embrapa Solos, 2006. 306p.

FILIZOLA, H.F. et al. Os fragipãs e duripãs das depressões dos Tabuleiros Costeiros do Nordeste brasileiro: uma proposta de evuloção. Revista Brasileira de Ciência do Solo, Viçosa, v.25, n.4, p.497-963, 2001.

GIAROLA, N.F.B. et al. Mineralogia e cristalografia da fração argila de horizontes coesos de solos nos Tabuleiros Costeiros. Revista Brasileira de Ciência do Solo, Viçosa, v.33, n.1, p.33-40, 2009.

GOMES, J.B.V. et al. Solos de três áreas de restinga. I. Morfologia, caracterização e classificação. Pesquisa Agropecuária Brasileira, Brasília, v.33, n.11, p.19071919, 1998.

GOMES, J.B.V. et al. Variabilidade espacial de atributos de solos em unidades de manejo em área piloto de produção integrada de côco. Revista Brasileira de Ciência do Solo, Viçosa, v.32, n.6, p.2471-2482, 2008.

KÄMPF, N.; CURI, N. Formação e evolução do solo (Pedogênese). In: KER, J.C. et al. Pedologia:

Fundamentos. Viçosa: SBCS, 2012, p.207-302.

LIMA, H.V. et al. Indentificação e caracterização de solos coesos no estado do Ceará. Revista Brasileira de Ciência do Solo, Viçosa, v. 28, n.3, p.467-476, 2004.

LIMA NETO, J.A. et al. Caracterização e gênese do caráter coeso em Latossolos Amarelos e Argissolos dos Tabuleiros Costeiros do Estado de Alagoas. Revista Brasileira de Ciência doSolo, Viçosa, v.33, n.4, p.10011011, 2009. 
LIMA NETO, J.A. et al. Atributos químicos, mineralógicos e micromorfológicos de horizontes coesos de Latossolos e Argissolos dos Tabuleiros Costeiros do Estado de Alagoas. Revista

Brasileira de Ciência do Solo, Viçosa, v.34, n.2, p.473-486, 2010.

MELO FILHO, J.F.; SOUZA, A.L.V.; SOUZA, L.S. Determinação do índice de qualidade subsuperficial em um Latossolo Amarelo coeso dos Tabuleiros Costeiros, sob Floresta Natural. Revista Brasileira de Ciência do Solo, Viçosa, v.31, n.6, p.1599-1608, 2007.

MELLO, C.R.; CURI, N. Hydropedology. Ciência e Agrotecnologia, Lavras, v.36, n.2, p.137-146, 2012.

MOREAU, A.M.S.S. et al. Caracterização de solos de duas topossequências em Tabuleiros Costeiros no sul da Bahia. Revista Brasileira de Ciência do Solo, Viçosa, v.30, n.6, p.1007-1019, 2006a.

MOREAU, A.M.S.S. et al. Gênese de horizonte coeso, fragipã e duripã em solos do Tabuleiro Costeiro do sul da Bahia. Revista Brasileira de Ciência do Solo, Viçosa, v.30, n.6, p.1021-1030, 2006b.

OLIVEIRA, A.P. et al. Spodosols pedogenesis under Barreiras Formation and Sandbank environments in the south of Bahia. Revista Brasileira de Ciência do Solo, Viçosa, v.34, n.3, p.847-860, 2010.
RESENDE, M. et al. Pedologia: base para distinção de ambientes. 5. ed. Lavras: Editora UFLA, 2007. 322p.

RESENDE, M. et al. Mineralogia de solos brasileiros: interpretação e aplicações. 2. ed. Lavras: Editora UFLA, 2011.201p.

SANTANA, M.S. et al. Atributos físicos do solo e distribuição do sistema radicular de citros como indicadores de horizontes coesos em dois solos de tabuleiros costeiros do Estado da Bahia. Revista Brasileira de Ciência do Solo, Viçosa, v.30, n.1, p.1-12, 2006.

SANTOS, R.D. et al. Manual de descrição e coleta de solo no campo. 5. ed. Viçosa: SBCS, 2005. 100p.

SAUER, D. et al. Review article podzol: soil of the year 2007. A review on its genesis, ocurrence, and functions. Journal of Plant Nutrition and Soil Science., Weinheim, v.170, n.5, p.581-597, 2007.

SILVA, F.B.R. et al. Zoneamento agroecológico do Nordeste: diagnóstico do quadro natural e agrossocioeconômico. Ed. 1. Petrolina: EmbrapaCPATSAe Embrapa-CNPS, 1993.387p.

SKIBA, M.; SKIBA, S. Chemical and mineralogical index of podzolisation of the Granite Regolith Soils. Polish Journal of Soil Science, Poland, v.38, n.2, p.153-161, 2005. 